\title{
Improving Student's Learning Outcomes on Natural Science Material Through Multimedia Learning Approach in Elementary School
}

\author{
Syarkani $^{1}$, Mursalin ${ }^{2}$ and Hanafiah ${ }^{3}$ \\ \{syarkani@gmail.com\} \\ ${ }^{1}$ Department of Early Childhood Education, Universitas Almuslim, Bireuen, Indonesia \\ ${ }^{2}$ Department of Mathematics Education, Universitas Malikussaleh, Aceh, Indonesia \\ ${ }^{3}$ Department of Historical Education, Universitas Samudra, Langsa, Indonesia
}

\begin{abstract}
This research paper aims to describe the improvement of students' learning outcomes on the subject of natural science through the approach of multimedia learning in elementary school. The research method used is Classroom Action Research Design. Data were collected through multiple choice test to find out the students' learning outcomes from each cycle, result of observation activities of teacher and student, and the result of a questionnaire of student response. The results of research obtained data that student learning outcomes in cycle 1 of $72 \%$ and increased by $24 \%$ to $96 \%$ in cycle II. Teacher activities in cycle I was $81 \%$ while in cycle II was $94 \%$, thus the increase of teacher activity by $13 \%$. Student activities in cycle 1 are $80 \%$ and in cycle II is $91 \%$. Increased student activities by $11 \%$. Student response to learning is very happy, where the expressed pleasure to statement component learning activities that researchers apply in the learning of $97.2 \%$. Thus it can be concluded that through the use of multimedia learning approaches on the subject of Natural Sciences can improving students learning outcomes, teacher activities and students as well as ongoing enjoyable learning as planned and get high responses from students.
\end{abstract}

Keywords: Students Learning Outcomes, Natural Sciences, Multimedia Learning Approach, Elementary School

\section{Introduction}

Learning is a complex process that occurs in every person throughout his life. The learning process occurs because of the interaction between a person and his environment. Therefore, learning can happen anytime and anywhere. One of the characteristics a person has learned is a change in behavior caused by a change in the level of knowledge, skills, or attitudes [1].

Robbins [2], defines learning as the process of creating a relationship between something (knowledge) that has been understood with something (knowledge) new. While Brunner [2], said that learning is an active process in which students build new knowledge based on experience/knowledge they already have. In the view of constructivism learning is not simply transferring knowledge beyond itself, but learning more about how the brain processes and interprets the new experience with the experience it already has in a new format. 
Burton [3], argued that learning is a process of behavioral change in the individual because of the interaction between individuals and individuals, individuals with their environment so that they are more able to interact with their environment. While Gagne [4], suggests that learning is a relatively sedentary behavior change resulting from past experiences or from planned/intended learning. Experience gained by individuals in their interactions with the environment, both unplanned and planned so as to produce relative sedentary changes.

The interactions that occur during the learning process are influenced by the environment, which includes students, teachers, librarians, principals, materials or materials (books, modules, leaflets, magazines, video or audio recordings, and the like), and various learning resources and facilities (overhead projectors, video and audio tape recorders, radio, television, computers, libraries, laboratories, learning resource centers, and so on).

The development of science and technology increasingly encourage renewal efforts in the utilization of technology results in the learning process [5]. In teachers are required to be able to use the tools that can be provided by the school, and it is possible that these tools in accordance with the development and demands of the times. Teachers can at least use cheap and efficient tools which, though simple and understated, are imperative in achieving the expected teaching objectives. Besides being able to use the tools available teachers are also required to be able to develop skills to create teaching media that will be used when the media is not available. For that teacher should have sufficient knowledge and understanding of teaching media. Seels \& Richey [6] explains that multimedia or integrated technology is a way to produce learning materials by combining several types of computer-controlled media. While Rosch defines multimedia is a combination of computers and videos or as suggested by McCormick that multimedia, in general, is a combination of three elements, namely voice, image and text [7].

Based on observations and interviews with teachers of State Elementary School 7 Paya Bakong, Aceh Utara, Aceh Province, Indonesia is the teacher in teaching always use the conventional motode and do not use any learning media. Both teachers and students tend to be passive and the learning process boring. Conditions like these are not motivated students to learn, so it affects the results of student learning. Students need a variety of learning media to create an active, creative and enjoyable teaching-learning environment in the classroom. So that seen from the students of State Elementary School 7 Paya Bakong they are not enthusiastic in following the lesson.

This, of course, affects the student's own learning outcomes. It is necessary to apply the multimedia learning approach that can encourage students to be more active, open to giving and receiving opinions, independent and responsible. So research formulate the problem; 1) How to improve student learning outcomes through learning multimedia approach? 2) How are the activities of teachers and students through the multimedia learning approach? 3) How are the student's response to the material form and its nature in class IV State Elementary School 7 Paya Bakong through multimedia learning approach?.

The purpose of this research is to know; 1) improvement of student learning outcomes 2) teacher activity and students 3 ) student response on material form and its nature in class IV State Elementary School 7 Paya Bakong through multimedia learning approach.

One effort that can be done is to use the multimedia learning approach. This learning multimedia can be used by teachers because it can bring students to the real world. Students are better able to absorb the information with the help of multimedia messenger tools so that in the learning process achievement can be achieved better. The multimedia functions of learning according to Suyanto [13] are as follows: 1) Able to attract the senses and attract students because, is a combination of views, sounds, and movement. 2) Being able to generate a sense of fun during the learning takes place, so it will increase student learning motivation. 
3) Be able to combine text, images, audio, music, animated images or video in a unity that support each other so as to achieve learning objectives. 4) Be able to visualize the real material. 5) The storage media is relatively easy and easy. 6) Bringing hard-to-reach or dangerous objects into the learning environment. 7) Displays objects that are too large for the class, and 8) Displays objects that can not be seen directly.

Endah Arnitasari [5] a study entitled "Interactive Multimedia Application of Science Learning". Explained that the application of interactive multimedia learning science for elementary school class VI. Along with the rapid development of information technology today, the multimedia computer has a very important role in the field of education. This is evidenced by the production of multimedia applications in the form of learning CDs that have been widely circulated in the market today. CD learning itself there are many kinds, both of which are interactive and non-interactive. For learning CDs created for sd kids, they will tend to be more fond of interactive applications because for them the app will be more interesting and effective to learn. This is what encourages the production of multimedia learning applications that are interactive.

The advantages of multimedia learning, in general, is the learning process more interesting, more interactive, the amount of teaching time can be reduced, the quality of student learning can be improved and the learning process can be done anywhere and anytime, and student learning attitudes can be improved. Warsita [16] suggests that learning with multimedia or integrated technology has the following characteristics: 1) Can be used randomly, in addition to linearly. 2) Can be used according to the learner's wishes in addition to the way as designed by the developer. 3) Ideas are often presented realistically in the context of learners' experiences. Relevant to the condition of learners, and under the control of learners (user). 4) Principles of cognitive learning theory and constructivism applied in developing and utilizing learning materials. 5) Learning is centered and organized according to cognitive knowledge so that knowledge is formed upon use. 6) Learning materials show high interactivity of learners. 7) Properties of materials that integrate words and examples from many media sources. Characteristics of multimedia learning are one of the computerbased learning media, which combines and synergize all media presented to learners with the aim to form knowledge after the implementation of learning takes place.

Learning media that have been selected to be used effectively and efficiently need to take steps systematically. This study uses pictures and videos as Warsita [16] says. There are three main steps that can be done: preparation, implementation of the presentation, and follow-up.

1) Preparation is the activity of a lecturer who will teach by using instructional media. Activities that can be done by teachers in preparatory steps include: making the implementation plan of learning as if to teach as usual. In the learning, implementation plan includes the media that will be used, study the user manual or accompanying materials that have been provided, prepare and organize the equipment that will be used so that the implementation will not rush and look for again and learners can see and hear with good.

2) Implementation/Presentation, Teachers while doing the learning process using learning media need to consider such as: make sure that all media and equipment are complete and ready to use, explain the objectives to be achieved, explain in advance what should be done by learners during the learning process, avoid events that may interfere with attention /concentration, and calm learners.

3) The follow-up, this activity needs to be done to strengthen learners' understanding of the material covered by the media. Besides, this activity is intended to measure the effectiveness of learning that has been done. Activities that can be done include discussion, observation, practice, and test 
Agustina [1] in a study entitled "Multimedia Utilization to Improve the Results of Science Classroom II students Theme of the Environment In SDN Ngembeh 1 Dlanggu" shows that the completeness of student learning outcomes in class I cycle for the subjects of Natural Sciences obtained a percentage of $60 \%$ or as many as 15 students who have completed learning, while 10 students do not complete learning with percentage $40 \%$. And the completeness of learning outcomes classically in the first cycle (first) Indonesian subjects get a percentage of $60 \%$ or as many as 15 students who have completed learning, while 10 students do not complete learning percentage $40 \%$. This result shows that cycle I have not reached the standard of completeness which is set $80 \%$ with average 70 not yet successful from the result of learning test on learning done, because student not yet accustomed to learning with the application of multimedia in the subject of Natural Science. the completeness of student learning outcomes classically in cycle II in cycle II subjects of Natural Sciences obtained percentage of $92 \%$ or as many as 23 students who have completed learning, while 2 students do not complete learning with percentage of $8 \%$, This result indicates that cycle II is good once, this is seen with the increase of the average of student learning outcomes from cycle II on subjects of Natural Sciences that is 68.4 to 90 . Learning completeness achieved in the second cycle of $92 \%$. This shows that the completeness of student learning outcomes classical in cycle II has reached the percentage set on the success indicator.

Multimedia learning is used by teachers will bring students to the real world, students are better able to absorb information with the aid of multimedia messenger tools, so that in the learning process achievement can be achieved better. One effort that can be done is to use the multimedia learning approach. This learning multimedia can be used by teachers because it can bring students to the real world. Students are better able to absorb the information with the help of multimedia messenger tools, so that in the learning process achievement can be achieved better. Based on the above description, the researcher is interested to choose the title "Improving Student's Learning Outcomes on Natural Science Material Through Multimedia Learning Approach in Elementary School".

\section{Methods}

This research was conducted at the State Elementary School 7 Paya Bakong, Blang Pante Village, Paya Bakong Sub-district, Aceh Utara District, Province of Aceh, Indonesia. This research was conducted on the students of class IV in the odd semester of the academic year 2016/2017 consisting of 23 students consist of 9 men and 14 women.

This research was conducted by the qualitative method by following the Classroom Action Research design. Therefore, this research is carried out by following the following stages: planning, implementation, action, observation, and reflection. This research takes two cycles with four actions. Sources of data obtained through questionnaires of teacher and student activities, test items as well as questionnaire responses of students. The test items that are prepared in the form of multiple choice items are given at the end of each cycle.

Further data obtained have been analyzed by using some equations, that is:

1. Calculating the improvement of student learning outcomes was analyzed by calculating the absorption for each cycle using the equation as follows:

$$
\text { Absorption }=\frac{\text { Number of Students Completed }}{\text { Number of Students }} \times 100 \%
$$


The results of calculation of absorptive power, then in use the criteria mastery in classical and invidual set by State Elementary School 7 Paya Bakong namely: individual mastery if students get the value of $\geq 75$, while the mastery of the classical if the absorption reaches $85 \%$.

2. Calculate teacher and student activity and calculate student response analyzed by using percentage, that is:

$$
P=\frac{f}{N} \times 100 \%
$$

3. Students Response

To find out student response by presenting answer from questionnaire given to student with descriptive statistic as follows:

$$
P=\frac{f}{N} x 100 \%
$$

Symbol Description:

$\mathrm{P}$ : Percentage calculated

f : Correct answer frequency

$\mathrm{N}$ :Number of questions

Table 1. Criteria for student response

\begin{tabular}{ccc}
\hline No. & Achievement Score Total & Category \\
\hline 1. & $86-100$ & Very good \\
2. & $70-85$ & Good \\
3. & $60-69$ & Enough \\
4. & $<60$ & Less \\
\hline
\end{tabular}

\section{Result}

\subsection{Description of Research Location}

Implementation of this research on the Class IV students of State Elementary School 7 Paya Bakong, Blang Pante Village, Paya Bakong Sub-district, Aceh Utara District, Province of Aceh, Indonesia, with conducted on the students of class IV in the odd semester of the academic year 2016/2017 consisting of 23 students consist of 9 men and 14 women. The study began on Thursday, October 26, 2017, to Friday, November 4, 2017.

In the course of this study, it was observed by two observers. Implementation of learning acts by using multimedia learning approaches on material object and its nature is done with two cycles.Cycle I consists of two meetings with the material being studied is the form and nature of the object. Cycle II consists of two meetings with material changes in the form of objects.

\subsection{Description of Research Actions}

Implementation of this research action conducted in 2 cycles, that is the cycle I and cycle II. Each cycle consists of 2 actions (teaching meeting). In action 1 of cycle 1 (first teaching meeting) the researcher teaches matter material form. While action 2 of cycle 1 (second teaching meeting) the researcher teaches the solute and the insoluble in water.

Cycle II consists of 2 actions (meeting 2 times) with material changes of matter (Solid $\rightarrow$ Liquid $\rightarrow$ Gas) in action 1 and the shape of the object (Solid $\rightarrow$ Gas $\rightarrow$ Solid) in action 2 . 
After preparing the completeness of the study, the researcher acting as a teacher, carry out the action on the Class IV students of State Elementary School 7 Paya Bakong observed by 2 observers to observe the implementation of the research.

\subsection{Description of Student'sLearning Outcomes}

The use of multimedia learning approach on material form and its nature in research conducted in class IV State Elementary School 7 Paya Bakong proved to improve student learning outcomes obtained from the analysis of the results of student learning outcomes in the cycle I and cycle II. Data on the improvement of student learning outcomes in cycle I and cycle II are presented in the table below:

Table 1. Percentage of Student's Learning Outcomes in Cycle I and Cycle II through the Use of Multimedia Approach to Learning on Material and Its Nature

\begin{tabular}{ccccc}
\hline \multirow{2}{*}{ No. } & Cycle & \multicolumn{2}{c}{ Student's Learning Outcomes } & \multirow{2}{*}{$\begin{array}{c}\text { Percentage } \\
\text { Enhancement }\end{array}$} \\
\cline { 3 - 4 } & & Mastery & Not Mastery & $24 \%$ \\
\hline 1. & Cycle I & $72 \%$ & $28 \%$ & \\
\hline 2. & Cycle II & $96 \%$ & $4 \%$ & \\
\hline
\end{tabular}

Based on table 1 above, it can be seen that in the first cycle there are 18 students complete the learning result with the acquisition value $>65$ so that the percentage of classical completeness of $72 \%$ and 7 students get the value of $\leq 65$ with the percentage of unfinished students by $28 \%$. While in cycle II there are 24 students complete the learning result with the acquisition value $>65$ so that the percentage of classical completeness of $96 \%$ and 1 student get the value of $\leq 65$ with the percentage of unfinished students of $4 \%$.

Based on this, after implementing the action cycle I and cycle II there is an increase in student learning outcomes as expected. Increased student learning outcomes from cycle I to cycle II by $24 \%$. Increasing the percentage of student learning outcomes from cycle I to cycle II which is the influence of the use of multimedia learning approaches on material form and its nature in learning, the improvement can be seen in figure 1 below.

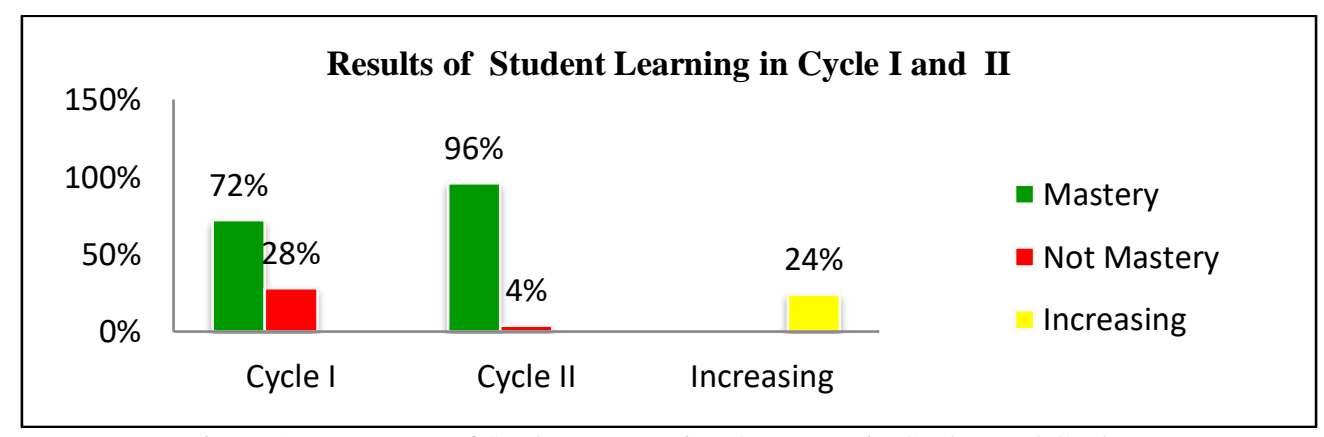

Figure 1. Percentage of Student's Learning Outcomes in Cycle I and Cycle II

\subsection{Description of Teacher's Activities}


Based on the observation of teacher activity during the learning activity, analyzed by using percentage. The analysis results for cycle I and cycle II can be seen in the table 2 below.

Table 2.Percentage of Teacher's Activities in Cycle I and II

\begin{tabular}{cccc}
\hline No & Cycle & Percentage & $\begin{array}{c}\text { Percentage } \\
\text { Enhancement }\end{array}$ \\
\hline 1. & Cycle I & $81 \%$ & $13 \%$ \\
\hline 2. & Cycle II & $94 \%$ & $13 \%$ \\
\hline
\end{tabular}

Based on table 2 above, it can be seen that the percentage of teacher activity in cycle I was obtained by $81 \%$ and teacher activity in cycle II was $94 \%$. Thus the increase in activities undertaken by teachers during the learning process lasted by $13 \%$. To know the percentage of teacher activity in cycle I and cycle II can be seen from figure 2 below.

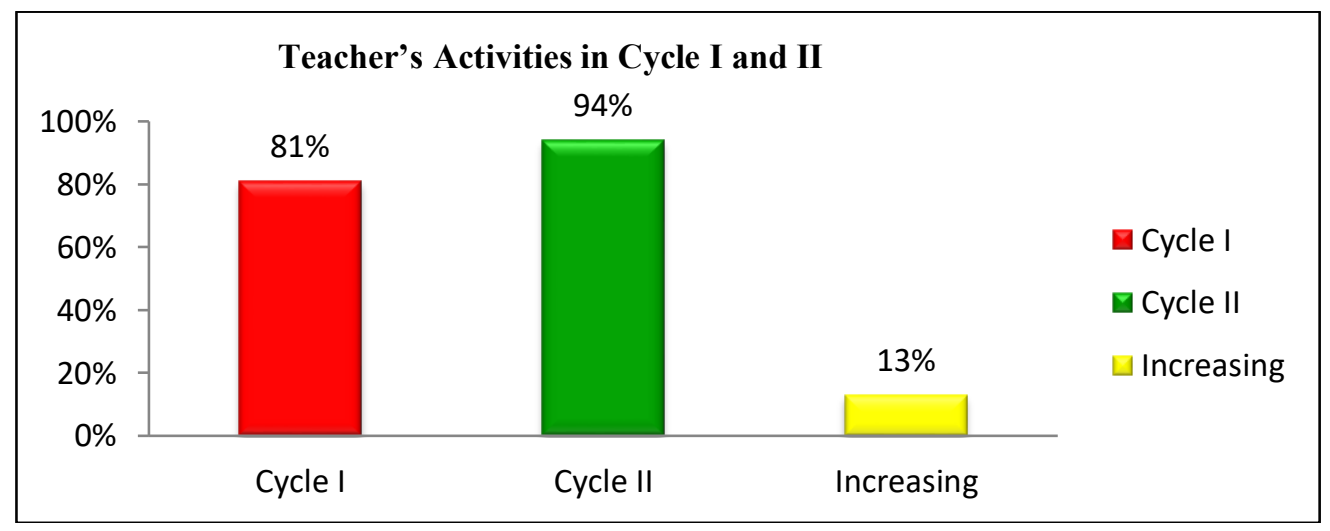

Figure 2. Percentage of Teacher's Activities in Cycle I and Cycle II

\subsection{Description of Student's Activities}

Based on the observation of student's activities during the learning activities is analyzed by using the percentage. The analysis results for cycle I and cycle II can be seen in the table below.

Table 3. Percentage of Student's Activities in Cycle I and II

\begin{tabular}{cccc}
\hline No & Cycle & Percentage & $\begin{array}{c}\text { Percentage } \\
\text { Enhancement }\end{array}$ \\
\hline 1. & Cycle I & $80 \%$ & $11 \%$ \\
\hline 2. & Cycle II & $91 \%$ & $11 \%$ \\
\hline
\end{tabular}

Based on table 3 above can be seen that the percentage of student's activities on the first cycle obtained by $80 \%$ and student's activities on the second cycle obtained by $91 \%$. Thus, the 
increase in activities conducted by students during the learning process lasted by $11 \%$. To know the percentage of student activity in cycle I and cycle II can be seen from figure 3 below.

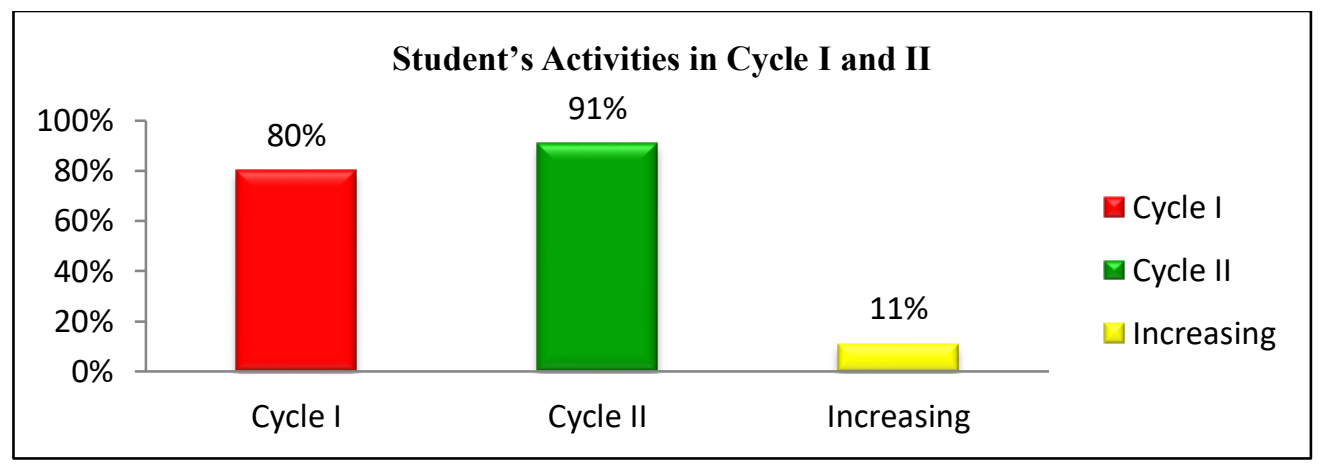

Figure 3. Percentage of Student's Activities in Cycle I and Cycle II.

\subsection{Description of Student's Responses}

To know the student responses to the implementation of learning through the use of multimedia learning approach on the material object and its properties obtained by using a questionnaire of student responses. The results obtained can be seen in the following table 4 below.

Table 4. Result of Student's Responses

\begin{tabular}{|c|c|c|c|}
\hline No & Statements & Happy & Not Happy \\
\hline 1. & $\begin{array}{l}\text { When starting the lesson the teacher shows a video } \\
\text { related to the material being studied. }\end{array}$ & 25 & 0 \\
\hline 2. & $\begin{array}{l}\text { Teachers ask questions to students based on video } \\
\text { impressions. }\end{array}$ & 24 & 1 \\
\hline 3. & $\begin{array}{l}\text { The teacher writes the learning objectives on the board and } \\
\text { ns the learning objectives to be learned to make it easier to } \\
\text { tand the learning materials. }\end{array}$ & 24 & 1 \\
\hline 4. & $\begin{array}{l}\text { Teachers form study groups consisting of } 4-5 \text { students } \\
\text { each group. }\end{array}$ & 24 & 1 \\
\hline 5. & $\begin{array}{l}\text { Each group is given a Student Worksheet relating to the } \\
\text { subject matter. }\end{array}$ & 25 & 0 \\
\hline 6. & $\begin{array}{l}\text { The teacher provides guidance to each group in working } \\
\text { on the Student Worksheet. }\end{array}$ & 24 & 1 \\
\hline 7. & Teachers provide reinforcement at the end of learning. & 23 & 2 \\
\hline 8. & $\begin{array}{l}\text { What do you feel when learning by using a multimedia } \\
\text { learning approach. }\end{array}$ & 25 & 0 \\
\hline 9. & $\begin{array}{l}\text { What if the teacher uses a multimedia learning approach } \\
\text { on other materials. }\end{array}$ & 25 & 0 \\
\hline 10. & $\begin{array}{l}\text { Teachers share the test questions for students to do the } \\
\text { cycles to determine the final ability of students after all } \\
\text { learning process finish. }\end{array}$ & 24 & 1 \\
\hline & Total & 243 & 7 \\
\hline
\end{tabular}


Graph to show percentage analysis of student response to statement of learning component can be seen as follows:

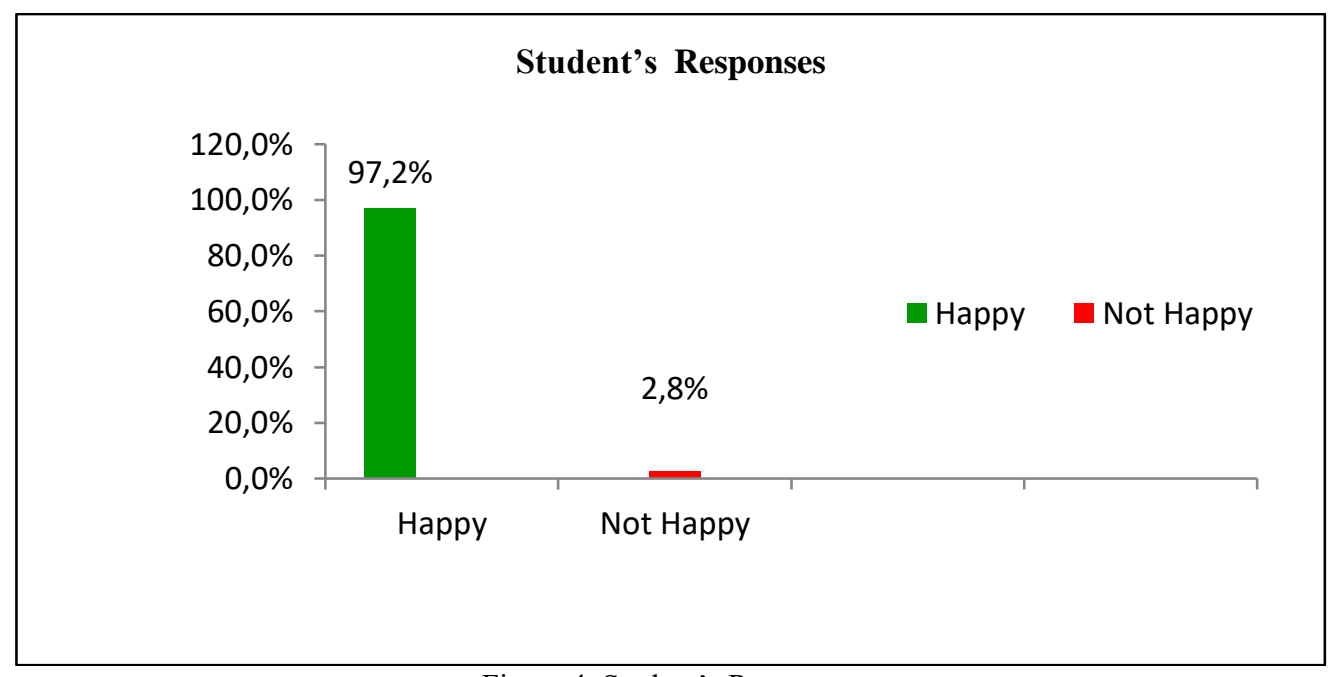

Figure 4. Student's Responses

Based on the questionnaire analysis of student responses during the implementation of teaching and learning process, it can be concluded that $97.2 \%$ of students answered happy with the statement that researchers apply in the implementation of learning by using multimedia learning approaches on material object and its properties, while $2.8 \%$ happy with the statement that the researchers apply in the implementation of learning by using the multimedia approach of learning on the material form and its nature thus the learning activities using the multimedia learning approach on the material form of the object and its fun for every student in the class and increase student interest in following the learning in the classroom and able to motivate in learning.

\section{Discussion}

The use of multimedia in learning is an attempt to create an atmosphere of creative and innovative learning without reducing the true learning objectives of a change in student behavior that can be measured and observed. Creating an interesting learning environment for students is certainly something to be achieved by teachers anywhere and anytime. By attracting the students' attention to the teaching and learning activities that teachers create, surely the students' learning motivation will increase as well as the understanding of the concept of the subject matter which of course has an impact on the students' learning outcomes which also increases.

The multimedia learning approach allows teachers to change teaching rules, where learning is no longer centered on the teacher but centered on the students. In the implementation of learning in the classroom, getting an interesting impression to follow the learning activities by students is an important and decisive first step for the achievement of 
expected learning objectives. In addition to the above, the use of multimedia learning also provides an important role in terms of being able to cause pleasure to students during the process of teaching and learning activities take place. This will increase students' motivation during the process of teaching and learning activities so that learning objectives can be achieved with the maximum.

The use of multimedia learning approach in material form and its nature has increased the activity undertaken by teachers during teaching and learning activities in which the percentage of activities undertaken by teachers in the first cycle of $81 \%$ and included in both categories, while in cycle II activities are undertaken by teachers increased to $94 \%$ and were included in the excellent category, thereby increasing teacher activity increased by $13 \%$.

Multimedia learning applied in the classroom is able to promote cooperative and interactive learning among students through discussion. Thus the use of multimedia learning on material form and its nature has increased the activities undertaken by students so that the implementation of learning has been going both ways between teachers and students and between students and students.

The use of multimedia learning on the material form and its nature can generate students' learning motivation because the multimedia learning makes the presentation of learning becomes more interesting. Thus, the use of multimedia learning approaches on material form and nature have been used effectively and efficiently teachers so that the purpose of the implementation has been achieved well. This can be seen from improving students' understanding of the material they have learned. The improvement of the students' understanding is obtained from the learning result that has increased, where the percentage of student learning outcomes classically in cycle I is $72 \%$ and increased by $24 \%$ in cycle II to $96 \%$.

In using the multimedia approach of learning on material form and nature, the teacher is able to generate a sense of fun during the learning process takes place so that will increase the motivation and interest of students in following the learning. This can be seen from the increase of activities conducted by students during the research activities conducted, in cycle I the percentage of activities undertaken by students during the learning took place by $80 \%$ and categorized well, then in cycle II there was an increase in student activity by $11 \%$ from the previous cycle to percentage of $91 \%$. Based on the data analysis of the percentage of activities undertaken by these students, the use of multimedia learning approach on target and successfully done with satisfactory results and as expected earlier.

Student response in learning by using multimedia learning approach also looks very happy, where $97,2 \%$ answer given by student stated that the learning that done by using learning multimedia approach is fun for the student, this is proven from student answer based on student response questionnaire. The use of a learning multimedia approach can replace most of the teacher's role as an informer or subject matter giver. It also affects the student's response to the learning implementation.

Positive responses and student interest in the material presented by the teacher can also generate students' learning motivation. The use of multimedia learning also allows students to absorb and remember the materials presented in the learning process. This will improve learning outcomes and achievement of the objectives of the learning activities themselves. Based on the above discussion, it can be concluded that the learning activities with multimedia learning approaches on material form and its properties can increase the activities undertaken by teachers and students during the learning process takes place. 


\section{Conclusions}

Based on the above discussion, the researcher can conclude that the results of the research conducted on the Class IV students of State Elementary School 7 Paya Bakong on material object and its nature by using multimedia learning approach are as follows:

1. Students' learning outcomes in the first cycle are $72 \%$ and included in the category enough, while the learning outcomes in the second cycle are $96 \%$ included in the category very well. Therefore, the increase that occurs after the implementation of the action cycle I to cycle II of $24 \%$.

2. Teacher activity in cycle I is $81 \%$ and in cycle II $94 \%$, from each cycle has increased as much as $13 \%$. Student activity in cycle I is $80 \%$ and in cycle II $91 \%$, from each cycle has increased as much as $11 \%$.

3. Student response looks very happy, where $97,2 \%$ student answer stated that the implementation of learning is fun and able to improve student understanding. Presentation of learning becomes more interesting because the teaching material is easily understood by students through the multimedia learning approach used by teachers

\section{Recommendation}

Based on the results of research, the researchers can provide suggestions to stakeholders are as follows.

1. The use of multimedia learning approach used in teaching and learning process provides opportunities for teachers to develop learning techniques, so as to obtain maximum results. Likewise for students, with the use of multimedia learning approaches it is expected they will be easier to determine with what and how students obtain information quickly and efficiently.

2. The use of multimedia learning approach by teachers can generate students' learning motivation, thus the use of multimedia learning approach can be used in all subjects.

\section{References}

[1] Agustina, Dyah Fitri. 2014. Pemanfaatan Multimedia Untuk Meningkatkan Hasil Belajar IPA siswa Kelas II Tema Lingkungan Di SDN Ngembeh 1 Dlanggu. (Online) http://ejournal.unesa.ac.id/article/15830/18/article.pdf.). Diakses 26/09/2017.

[2] Asrori, Mohammad. 2009. Penelitian Tindakan Kelas. Bandung: Wacana Prima.

[3] Devi dan Anggraeni. 2008. Ilmu Pengetahuan Alam untuk SD/MI Kelas IV. Jakarta: Depdiknas

[4] Dimyati dan Mudjiono. 2009. Belajar dan Pembelajaran. Jakarta: PT Rineka Cipta.

[5] Endah Arnitasari. (2015). aplikasi multimedia interaktif pembelajaran ipa. Surakarta: Universitas Negeri Sebelas Maret. aplikasi multimedia interaktif pembelajaran ipa untuk sekolah dasar kelas VI (Online) (http://dokumen.tips/documents/jurnal-aplikasi-multimedia-interaktif-pembelajaranipa-untuk-sekolah-dasar.html. Diakses 26/09/2017

[6] Fonna, M., \& Mursalin, M. (2018). Role of Self-Efficacy Toward Students' Achievement in Mathematical Multiple Representation Ability (MMRA). Jurnal Ilmiah Peuradeun, 6(1), 31-40. 
[7] Muhammad, I., Nufus, H., Mursalin, M. (2017).Peningkatan Kemampuan Komunikasi Matematika Melalui Pembelajaran KooperatifTipe STAD (Student Teams Achievement Division) Berbasis ICT (Information and Communication Technologies). Jurnal Kajian Pembelajaran Matematika, 1(2).pp.113-118

[8] Purwanto. 2011. Evaluasi Hasil Belajar. Yogyakarta:Pustaka Pelajar

[9] Siregar, Eveline dan Nara, Hartini. 2010. Teori Belajar dan Pembelajaran. Bogor: Ghalia Indonesia

[10] Sulistyanto dan Wiyono. 2008. Ilmu Pengetahuan Alam untuk SD/MI Kelas IV. Jakarta: Depdiknas

[11] Sukmadinata, Nana Syaodih. 2007. Landasan Psikologi Proses Pendidikan. Bandung: PT. Remaja Rosdakarya

[12] Sutopo, Ariesto Hadi. 2003. Interaksi dengan Flash. Yogyakarta: Graha Ilmu

[13] Suyanto, M. 2005. Multimedia Alat untuk Meningkatkan Keunggulan Bersaing. Yogyakarta: C.V. Andi O

[14] Tim Penyusun, 2013. Pedoman Penulisan Skripsi Bireuen. FKIP UNIMUS

[15] Trianto. 2011. Mendesain Model Pembelajaran Inovatif-Progresif. Jakarta: Kencana Prenada Media Group

[16] Warsita, Bambang. 2008. Teknologi Pembelajaran, Landasan dan Aplikasinya. Jakarta: Rineka Cipta 